\title{
Pengaruh Perubahan Konfigurasi Elektrode Batang Tunggal Dengan Penambahan Campuran Gypsum dan Arang Terhadap Tahanan Pentanahan
}

Deni Jamalludin ${ }^{1}$, Haerul Pathoni ${ }^{1}$, Abdul Manab ${ }^{1}$

${ }^{1}$ Program Studi Teknik Elektro, Fakultas Sains dan Teknologi, Universitas Jambi, Indonesia Email: djamalludin03@gmail.com, haerul.pathoni@gmail.com, am@unja.ac.id

\section{Info Artikel}

Diterima: 4 Januari 2021

Disetujui: 21 Januari 2021

Dipublikasikan: 29 Januari 2021

Alamat Korespondensi: djamalludin03@gmail.com

Copyright (c) 2021 Jurnal Engineering

This work is licensed under the Creative Commons Attribution International License (CC BY 4.0).

\begin{abstract}
Abstrak :
Penelitian ini bertujuan untuk mengetahui nilai tahanan pentanahan elektrode batang tunggal berdiameter berbeda, dengan konfigurasi penanaman secara vertikal dan horizontal serta ditambahkan campuran gypsum (G) dan arang (A) sebagai soil treatment. Penelitian ini menggunakan metode observasi dan pengukuran langsung. Teknik analisis data dalam penelitian ini menggunakan teknik analisis data deskriptif. Hasil untuk diameter elektrode $12 \mathrm{~mm}$ baik penanaman secara vertikal maupun horizontal, semakin besar perbandingan campuran gypsum dan arang yang digunakan dan semakin lama penanamannya akan mempengaruhi penurunan nilai tahanan. Dari hasil pengukuran tersebut dengan merubah konfigurasi penanaman elektrode batang dapat menurunkan nilai tahanan pentanahan sebesar $20 \%$. Sedangkan untuk elektrode diameter $16 \mathrm{~mm}$ sama halnya dengan elektrode $12 \mathrm{~mm}$, namun dengan merubah diameter elektrode menjadi lebih besar maka nilai tahanan pentanahan akan semakin turun, hal ini sesuai dengan nilai tahanan yang didapatkan dari pengukuran yang dilakukan secara langsung dilapangan. Dan merubah konfigurasi penanamannya dari vertikal ke horizontal dapat menurunkan nilai tahanan sebesar $13 \%$. Dengan tambahan campuran gypsum dan arang yang bervariasi dan mengubah diameter elektrode batang tunggal 12 $\mathrm{mm}$ menjadi $16 \mathrm{~mm}$ dapat menurunkan nilai tahanan pentanahan sebesar $12 \%$.
\end{abstract}

Kata kunci: Arang; Elektrode; Gypsum; Sistem Pentanahan 


\section{Pendahuluan}

Sistem pentanahan mulai dikenal pada tahun 1900. Sebelumnya sistem- sistem tenaga listrik tidak ditanahkan karena ukurannya masih kecil dan tidak membahayakan, namun setelah sistem-sistem tenaga listrik berkembang semakin besar dengan tegangan yang semakin tinggi dan jarak jangkauan semakin jauh, baru diperlukan sistem pentanahan (Muliansyah, 2016). Jika tidak dilakukan, maka akan membahayakan manusia, peralatan bahkan sistem itu sendiri.

Pentanahan merupakan suatu mekanisme dimana daya listrik dihubungkan langsung dengan tanah (bumi) (Abidin \& Ghufron, 2005). Sistem yang terdiri dari semua koneksi pentanahan yang saling berhubungan dalam sistem tenaga tertentu dan ditentukan oleh isolasinya dari sistem pentanahan yang berdekatan (IEEE Std, 2007). Sedangkan pentanahan peralatan adalah penghubungan bagian-bagian peralatan listrik pada keadaan normal tidak dialiri arus. Pentanahan sebagai cara untuk menghilangkan muatan listrik statis untuk mencegah percikan api ini dan mengamankan peralatan listrik, kondisi normal maupun saat terjadi gangguan (Abidin \& Ghufron, 2005). Jika arus hubung singkat dipaksakan mengalir ke tanah dengan tahanan yang tinggi akan menimbulkan perbedaan potensial yang besar dan berbahaya. Pembumian titik netral sistem tenaga dan pentanahan peralatan merupakan dua fungsi dari sistem pentanahan. Pentanahan netral sistem tenaga berfungsi sebagai pengaman sistem atau jaringan, sedangkan pada pentanahan peralatan berfungsi sebagai pengaman terhadap tegangan sentuh. Pentanahan mula-mula dilakukan dengan menanamkan batang elektrode pentanahan secara vertikal dan horizontal. Kemudian batang elektrode pentanahan itu di tanam kedalam tanah dengan kedalaman yang telah di tentukan. Hal ini dilakukan untuk mencapai nilai tahanan pentanahan yang baik berdasarkan PUIL (Persyaratan Umum Instalasi Listrik) yaitu tidak lebih dari 5 ohm (PUIL, 2000).

Secara singkat tujuan pengetanahan itu dapat diformulasikan sebagai berikut :

a. Mencegah terjadinya tegangan kejut listrik yang berbahaya disekitar area.

b. Meningkatkan keandalan (realibility) pelayanan dalam penyaluran tenaga listrik.

c. Untuk memudahkan dalam menentukan sistem proteksi serta memudahkan dalam menentukan lokasi gangguan. (80-2000, IEEE Std, 2000).

Pengukuran tahanan pentanahan dilakukan dengan menggunakan Earth Tester Dengan Metode 3 Titik. Alat ukur tahanan pentanahan ini adalah jenis digital resistance earth tester.

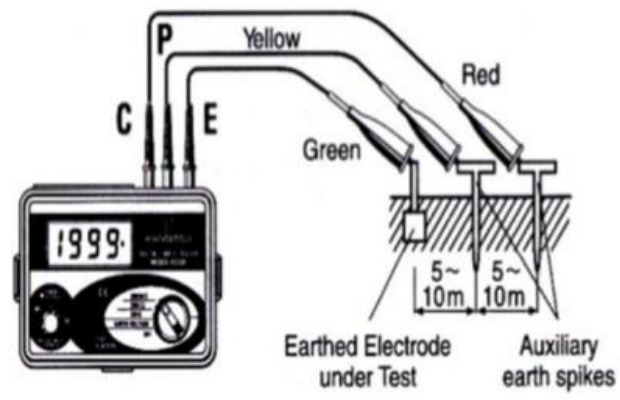

Gambar 1 Pengukuran tahanan pentanahan dengan metode tiga titik

Susunan elektrode pentanahan dapat dibedakan menjadi dua, yaitu pentanahan elektrode yang ditanam secara vertikal dan pentanahan elektrode yang ditanam secara horizontal. Gypsum sebagai zat aditif yang digunakan untuk mengubah komposisi kimia tanah, mempunyai nilai kelarutan yang rendah sehingga tidak mudah hilang. Campuran gypsum dan arang dapat ditambahkan sebagai soil treatment. 


\section{Metode Penelitian}

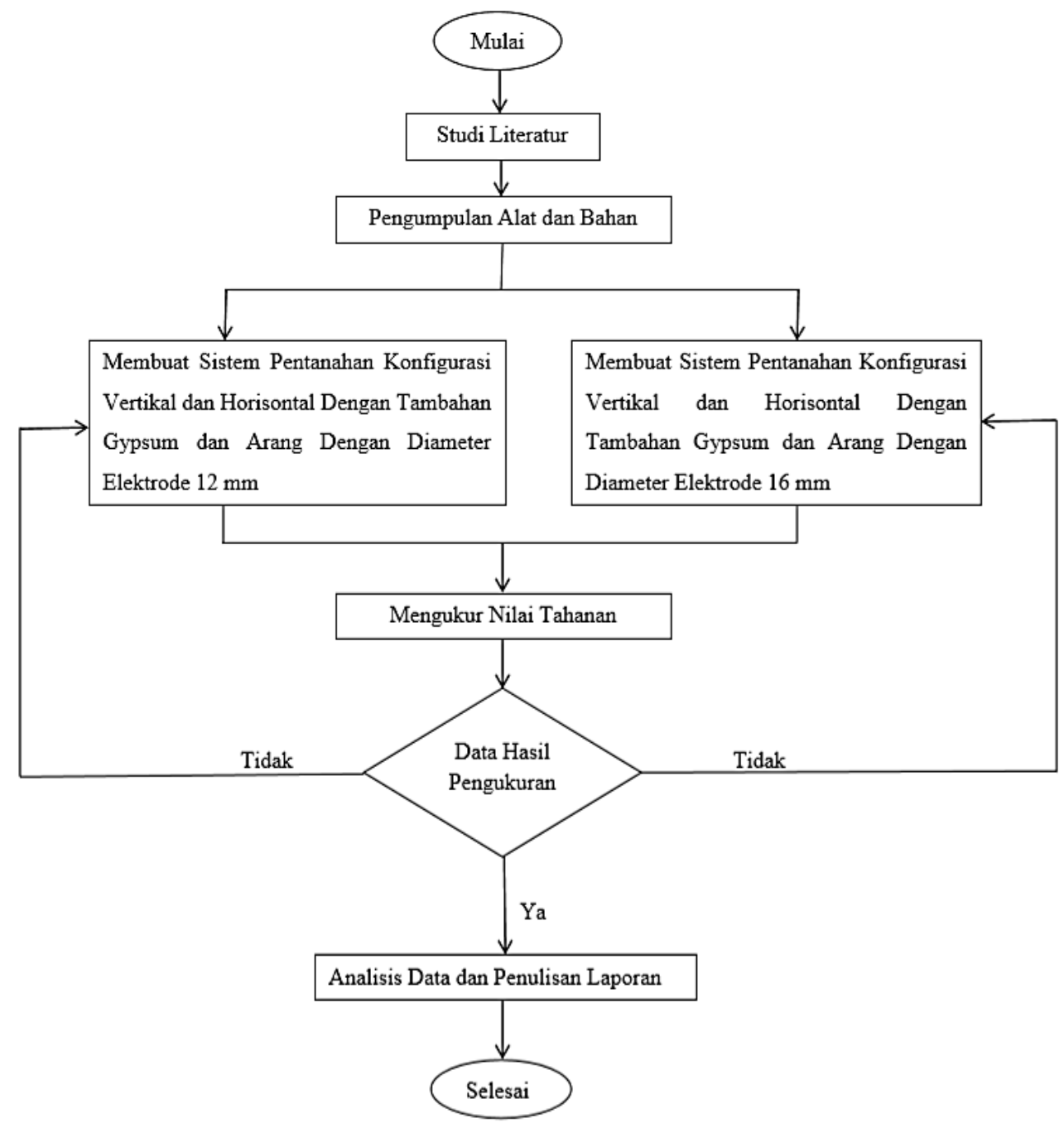

Gambar 2 Diagram alir penelitian

Metode Pengukuran nilai tahanan pentanahan dilakukan dengan metode 3 titik (three point method) dengan alat ukur digital earth tester Kyoritsu KEW 4105A.

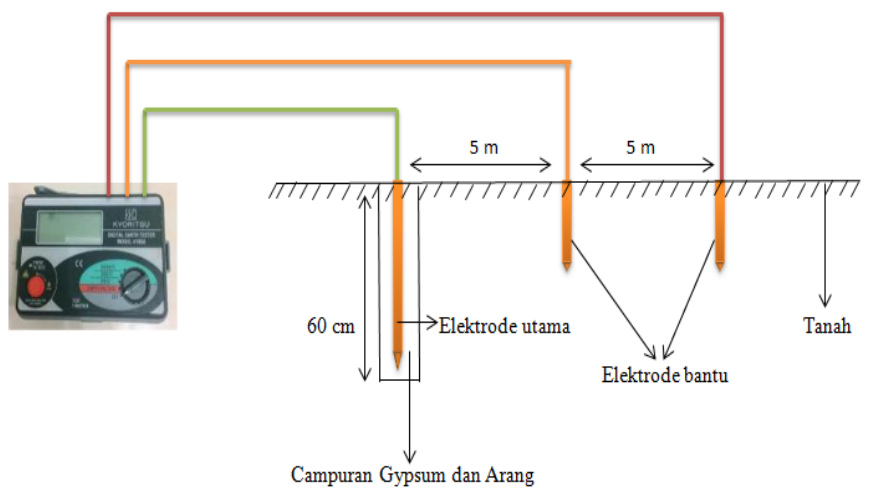

Gambar 3 Skematik rangkaian pengujian konfigurasi vertikal 


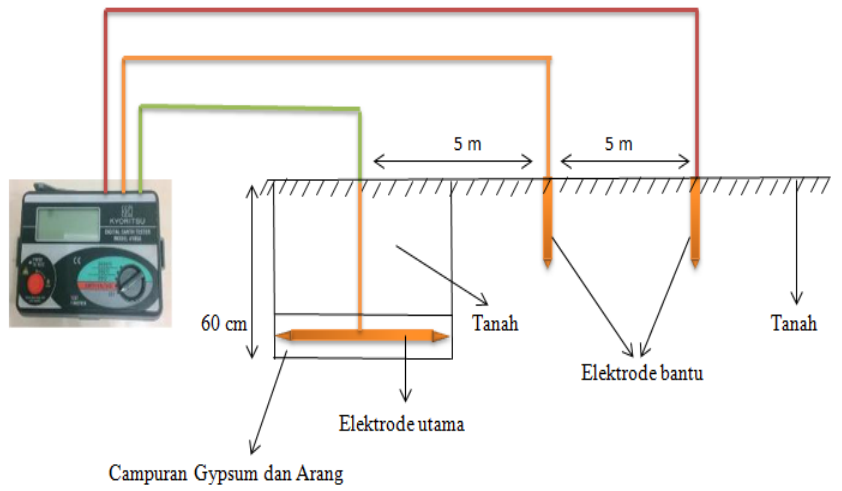

Gambar 4 Skematik rangkaian pengujian konfigurasi horizontal

\section{Hasil Penelitian dan Pembahasan}

A. Data Hasil Pengukuran tahanan elektrode tanpa campuran gypsum dan arang.

Tabel 1 Hasil Pengukuran Tahanan Pentanahan Elektrode Diameter 12 mm Tanpa Campuran Gypsum dan Arang

\begin{tabular}{c|c|c|c|c|c|c}
\hline \multirow{2}{*}{ NO } & \multirow{2}{*}{ Hari } & \multirow{2}{*}{ Jam } & \multicolumn{4}{|c}{ Tahanan dan kelembaban tanah } \\
\cline { 4 - 7 } & & & $\begin{array}{c}\text { Tahanan }(\Omega) \\
\text { Vertikal }\end{array}$ & $\begin{array}{c}\text { Kelembaban } \\
\text { tanah }(\%)\end{array}$ & $\begin{array}{c}\text { Tahanan }(\Omega) \\
\text { Horizontal }\end{array}$ & $\begin{array}{c}\text { Kelembaban } \\
\text { tanah(\%) }\end{array}$ \\
\hline \multirow{2}{*}{1} & 1 & 07.00 & $279 \Omega$ & $6 \%$ & $217 \Omega$ & $7 \%$ \\
\cline { 3 - 7 } & & 16.00 & $283 \Omega$ & $5 \%$ & $224 \Omega$ & $5 \%$ \\
\hline \multirow{2}{*}{2} & 2 & 07.00 & $291 \Omega$ & $5 \%$ & $218 \Omega$ & $8 \%$ \\
\cline { 3 - 7 } & \multirow{2}{*}{3} & 16.00 & $289 \Omega$ & $3 \%$ & $215 \Omega$ & $6 \%$ \\
\hline & 07.00 & $294 \Omega$ & $4 \%$ & $220 \Omega$ & $6 \%$ \\
\hline \multicolumn{2}{c}{ Rata-rata } & 16.00 & $290 \Omega$ & $3 \%$ & $223 \Omega$ & $5 \%$ \\
\hline
\end{tabular}

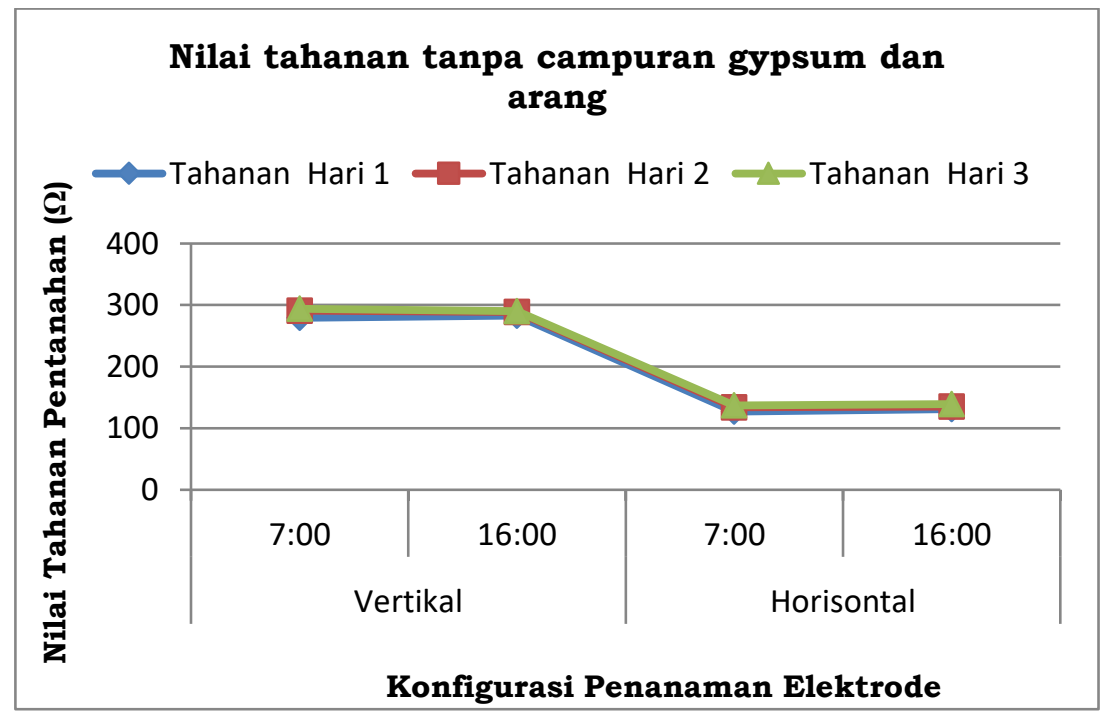

Gambar 5 Grafik nilai tahanan pentanahan elektrode $12 \mathrm{~mm}$ tanpa campuran gypsum dan arang 
Tabel 2 Hasil Pengukuran Tahanan Pentanahan Elektrode Diameter 16 mm Tanpa Campuran Gypsum dan Arang

\begin{tabular}{|c|c|c|c|c|c|c|}
\hline \multirow[b]{2}{*}{$\mathrm{NO}$} & \multirow[b]{2}{*}{ Hari } & \multirow[b]{2}{*}{ jam } & \multicolumn{4}{|c|}{ Tahanan dan kelembaban tanah } \\
\hline & & & $\begin{array}{c}\text { Tahanan }(\Omega) \\
\text { vertikal }\end{array}$ & $\begin{array}{c}\text { Kelembaban } \\
\operatorname{tanah}(\%)\end{array}$ & $\begin{array}{c}\text { Tahanan }(\Omega) \\
\text { Horizontal }\end{array}$ & $\begin{array}{c}\text { Kelembaban } \\
\operatorname{tanah}(\%)\end{array}$ \\
\hline \multirow[t]{2}{*}{1} & \multirow[t]{2}{*}{1} & 07.00 & $195 \Omega$ & $6 \%$ & $127 \Omega$ & $8 \%$ \\
\hline & & 16.00 & $194 \Omega$ & $5 \%$ & $131 \Omega$ & $7 \%$ \\
\hline \multirow[t]{2}{*}{2} & \multirow[t]{2}{*}{2} & 07.00 & $199 \Omega$ & $5 \%$ & $134 \Omega$ & $8 \%$ \\
\hline & & 16.00 & $197 \Omega$ & $3 \%$ & $135 \Omega$ & $6 \%$ \\
\hline \multirow[t]{2}{*}{3} & \multirow[t]{2}{*}{3} & 07.00 & $203 \Omega$ & $4 \%$ & $137 \Omega$ & $6 \%$ \\
\hline & & 16.00 & $195 \Omega$ & $3 \%$ & $139 \Omega$ & $5 \%$ \\
\hline \multicolumn{3}{|c|}{ Rata-rata } & $197,2 \Omega$ & $4 \%$ & $133,83 \Omega$ & $6 \%$ \\
\hline
\end{tabular}

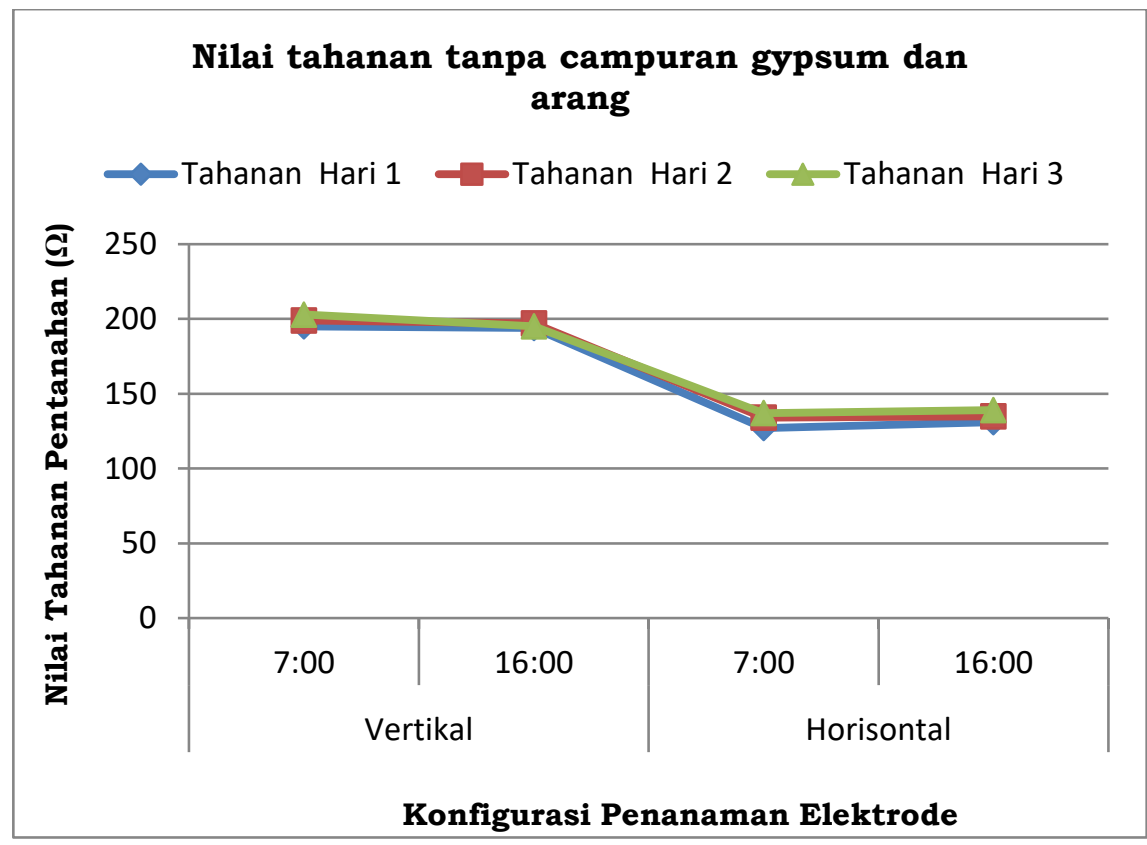

Gambar 6 Grafik hasil pengukuran tahanan pentanahan elektrode $16 \mathrm{~mm}$ tanpa gypsum dan arang 
B. Data Hasil Pengukuran tahanan elektrode dengan campuran gypsum dan arang.

Tabel 3 Hasil Pengukuran Tahanan Pentanahan Elektrode 12 mm (vertikal) dengan Campuran Gypsum dan Arang

\begin{tabular}{|c|c|c|c|c|c|c|c|c|}
\hline \multirow{3}{*}{$\mathrm{NO}$} & \multirow{3}{*}{ Hari } & \multirow{3}{*}{ Jam } & \multicolumn{6}{|c|}{ Tahanan dan kelembaban tanah } \\
\hline & & & \multicolumn{3}{|c|}{$\begin{array}{c}\text { Tahanan elektrode } 12 \mathrm{~mm}(\Omega) \\
\text { (Vertikal) }\end{array}$} & \multicolumn{3}{|c|}{ Kelembaban tanah (\%) } \\
\hline & & & $\begin{array}{l}\mathrm{G}: \mathrm{A} \\
0,5 \mathrm{Kg}\end{array}$ & $\begin{array}{c}\mathrm{G}: \mathrm{A} \\
0,75 \mathrm{Kg}\end{array}$ & $\begin{array}{l}\mathrm{G}: \mathrm{A} \\
1 \mathrm{Kg}\end{array}$ & $\begin{array}{c}\mathrm{G}: \mathrm{A} \\
0,5 \mathrm{Kg}\end{array}$ & $\begin{array}{c}\mathrm{G}: \mathrm{A} 0,75 \\
\mathrm{Kg}\end{array}$ & $\begin{array}{l}\mathrm{G}: \mathrm{A} \\
1 \mathrm{Kg}\end{array}$ \\
\hline \multirow[t]{2}{*}{1} & \multirow[t]{2}{*}{1} & 07.00 & $172,1 \Omega$ & $96,5 \Omega$ & $65,0 \Omega$ & $10 \%$ & $10 \%$ & $7 \%$ \\
\hline & & 16.00 & $165,6 \Omega$ & $91,9 \Omega$ & $63,8 \Omega$ & $7 \%$ & $8 \%$ & $7 \%$ \\
\hline \multirow[t]{2}{*}{2} & \multirow[t]{2}{*}{2} & 07.00 & $163,6 \Omega$ & $80,2 \Omega$ & $63,7 \Omega$ & $8 \%$ & $8 \%$ & $8 \%$ \\
\hline & & 16.00 & $160,3 \Omega$ & $76,4 \Omega$ & $61,2 \Omega$ & $7 \%$ & $9 \%$ & $9 \%$ \\
\hline \multirow[t]{2}{*}{3} & \multirow[t]{2}{*}{3} & 07.00 & $153,9 \Omega$ & $75,0 \Omega$ & $60,2 \Omega$ & $10 \%$ & $7 \%$ & $8 \%$ \\
\hline & & 16.00 & $152,4 \Omega$ & $74,1 \Omega$ & $59,8 \Omega$ & $7 \%$ & $7 \%$ & $8 \%$ \\
\hline \multicolumn{3}{|c|}{ Rata-rata } & $161,32 \Omega$ & $82,35 \Omega$ & $62,3 \Omega$ & $8,2 \%$ & $8,2 \%$ & $7,8 \%$ \\
\hline
\end{tabular}

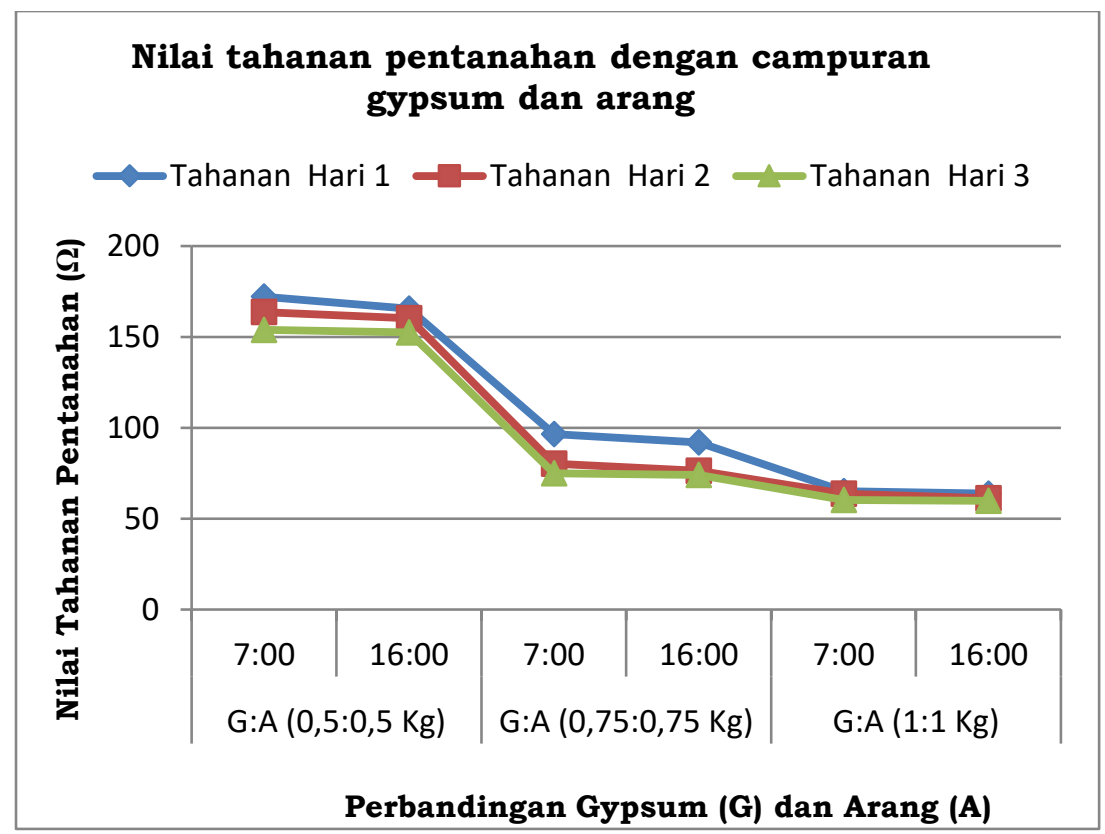

Gambar 7 Grafik hasil pengukuran tahanan pentanahan elektrode $12 \mathrm{~mm}$ secara vertikal dengan campuran gypsum dan arang 
Volume 3 Nomor 1, Januari 2021

Tabel 3 Hasil Pengukuran Tahanan Pentanahan Elektrode $12 \mathrm{~mm}$ (horizontal) dengan Campuran Gypsum dan Arang

\begin{tabular}{|c|c|c|c|c|c|c|c|c|}
\hline \multirow{3}{*}{$\mathrm{NO}$} & \multirow{3}{*}{ Hari } & \multirow{3}{*}{ Jam } & \multicolumn{6}{|c|}{ Tahanan dan kelembaban tanah } \\
\hline & & & \multicolumn{3}{|c|}{$\begin{array}{c}\text { Tahanan elektrode } 12 \mathrm{~mm}(\Omega) \\
\text { (Horizontal) }\end{array}$} & \multicolumn{3}{|c|}{ Kelembaban tanah (\%) } \\
\hline & & & $\begin{array}{l}\mathrm{G}: \mathrm{A} \\
0,5 \mathrm{Kg}\end{array}$ & $\begin{array}{c}\mathrm{G}: \mathrm{A} \\
0,75 \mathrm{Kg}\end{array}$ & $\begin{array}{l}\mathrm{G}: \mathrm{A} \\
1 \mathrm{Kg}\end{array}$ & $\begin{array}{c}\mathrm{G}: \mathrm{A} \\
0,5 \mathrm{Kg}\end{array}$ & $\begin{array}{c}\mathrm{G}: \mathrm{A} 0,75 \\
\mathrm{Kg}\end{array}$ & $\begin{array}{l}\mathrm{G}: \mathrm{A} \\
1 \mathrm{Kg}\end{array}$ \\
\hline \multirow[t]{2}{*}{1} & \multirow[t]{2}{*}{1} & 07.00 & $132,8 \Omega$ & $82,8 \Omega$ & $52,9 \Omega$ & $8 \%$ & $8 \%$ & $8 \%$ \\
\hline & & 16.00 & $126,2 \Omega$ & $79,6 \Omega$ & $52,7 \Omega$ & $6 \%$ & $9 \%$ & $7 \%$ \\
\hline \multirow[t]{2}{*}{2} & \multirow[t]{2}{*}{2} & 07.00 & $117,3 \Omega$ & $73,2 \Omega$ & $49,5 \Omega$ & $7 \%$ & $8 \%$ & $8 \%$ \\
\hline & & 16.00 & $112,9 \Omega$ & $73,7 \Omega$ & $48,7 \Omega$ & $5 \%$ & $8 \%$ & $8 \%$ \\
\hline \multirow[t]{2}{*}{3} & \multirow[t]{2}{*}{3} & 07.00 & $106,6 \Omega$ & $74,3 \Omega$ & $48,9 \Omega$ & $8 \%$ & $7 \%$ & $7 \%$ \\
\hline & & 16.00 & $103,4 \Omega$ & $74,7 \Omega$ & $48,8 \Omega$ & $9 \%$ & $6 \%$ & $7 \%$ \\
\hline \multicolumn{3}{|c|}{ Rata-rata } & $116,53 \Omega$ & $76,4 \Omega$ & $50,25 \Omega$ & $7,2 \%$ & $7,6 \%$ & $7,5 \%$ \\
\hline
\end{tabular}

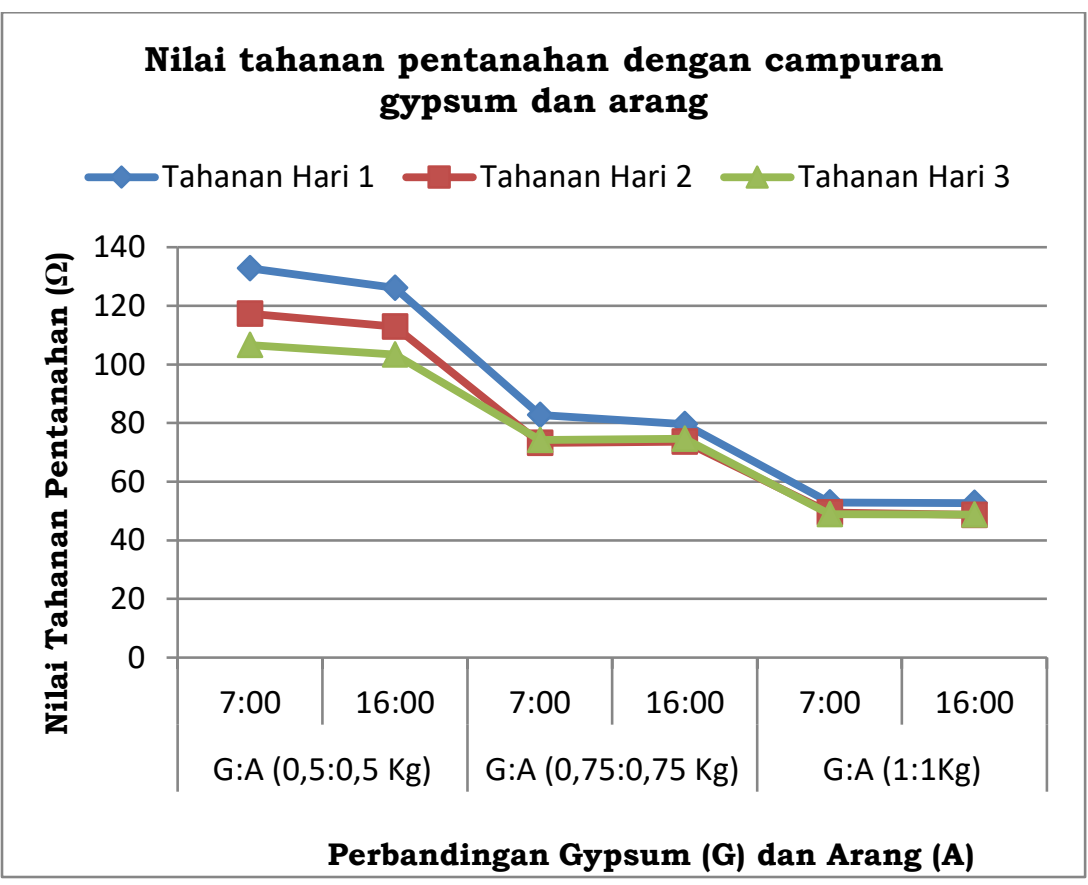

Gambar 8 Grafik hasil pengukuran tahanan pentanahan elektrode $12 \mathrm{~mm}$ secara horizontal dengan campuran gypsum dan arang 
Volume 3 Nomor 1, Januari 2021

Tabel 4 Hasil Pengukuran Tahanan Pentanahan Elektrode $16 \mathrm{~mm}$ (vertikal) dengan Campuran Gypsum dan Arang

\begin{tabular}{|c|c|c|c|c|c|c|c|c|}
\hline \multirow{3}{*}{ NO } & \multirow{3}{*}{ Hari } & \multirow{3}{*}{ Jam } & \multicolumn{6}{|c|}{ Tahanan dan kelembaban tanah } \\
\hline & & & \multicolumn{3}{|c|}{$\begin{array}{c}\text { Tahanan elektrode } 16 \mathrm{~mm}(\Omega) \\
\text { (Vertikal) }\end{array}$} & \multicolumn{3}{|c|}{ Kelembaban tanah (\%) } \\
\hline & & & $\begin{array}{l}\mathrm{G}: \mathrm{A} \\
0,5 \mathrm{Kg}\end{array}$ & $\begin{array}{c}\mathrm{G}: \mathrm{A} \\
0,75 \mathrm{Kg}\end{array}$ & $\begin{array}{l}\mathrm{G}: \mathrm{A} \\
1 \mathrm{Kg}\end{array}$ & $\begin{array}{l}\mathrm{G}: \mathrm{A} \\
0,5 \mathrm{Kg}\end{array}$ & $\begin{array}{c}\mathrm{G}: \mathrm{A} \\
0,75 \mathrm{Kg}\end{array}$ & $\begin{array}{l}\mathrm{G}: \mathrm{A} \\
1 \mathrm{Kg}\end{array}$ \\
\hline \multirow[t]{2}{*}{1} & \multirow[t]{2}{*}{1} & 07.00 & $124 \Omega$ & $80,1 \Omega$ & $53,9 \Omega$ & $8 \%$ & $8 \%$ & $8 \%$ \\
\hline & & 16.00 & $122 \Omega$ & $71,4 \Omega$ & $51,9 \Omega$ & $7 \%$ & $9 \%$ & $9 \%$ \\
\hline \multirow[t]{2}{*}{2} & \multirow[t]{2}{*}{2} & 07.00 & $119 \Omega$ & $70,4 \Omega$ & $51,8 \Omega$ & $6 \%$ & $8 \%$ & $8 \%$ \\
\hline & & 16.00 & $118 \Omega$ & $69,8 \Omega$ & $51,1 \Omega$ & $5 \%$ & $8 \%$ & $7 \%$ \\
\hline \multirow[t]{2}{*}{2} & \multirow[t]{2}{*}{3} & 07.00 & $114 \Omega$ & $70,9 \Omega$ & $51 \Omega$ & $6 \%$ & $7 \%$ & $7 \%$ \\
\hline & & 16.00 & $110 \Omega$ & $69,8 \Omega$ & $52,1 \Omega$ & $4 \%$ & $7 \%$ & $7 \%$ \\
\hline \multicolumn{3}{|c|}{ Rata-rata } & $117,83 \Omega$ & $72,1 \Omega$ & $52 \Omega$ & $6 \%$ & $7,8 \%$ & $7,7 \%$ \\
\hline
\end{tabular}

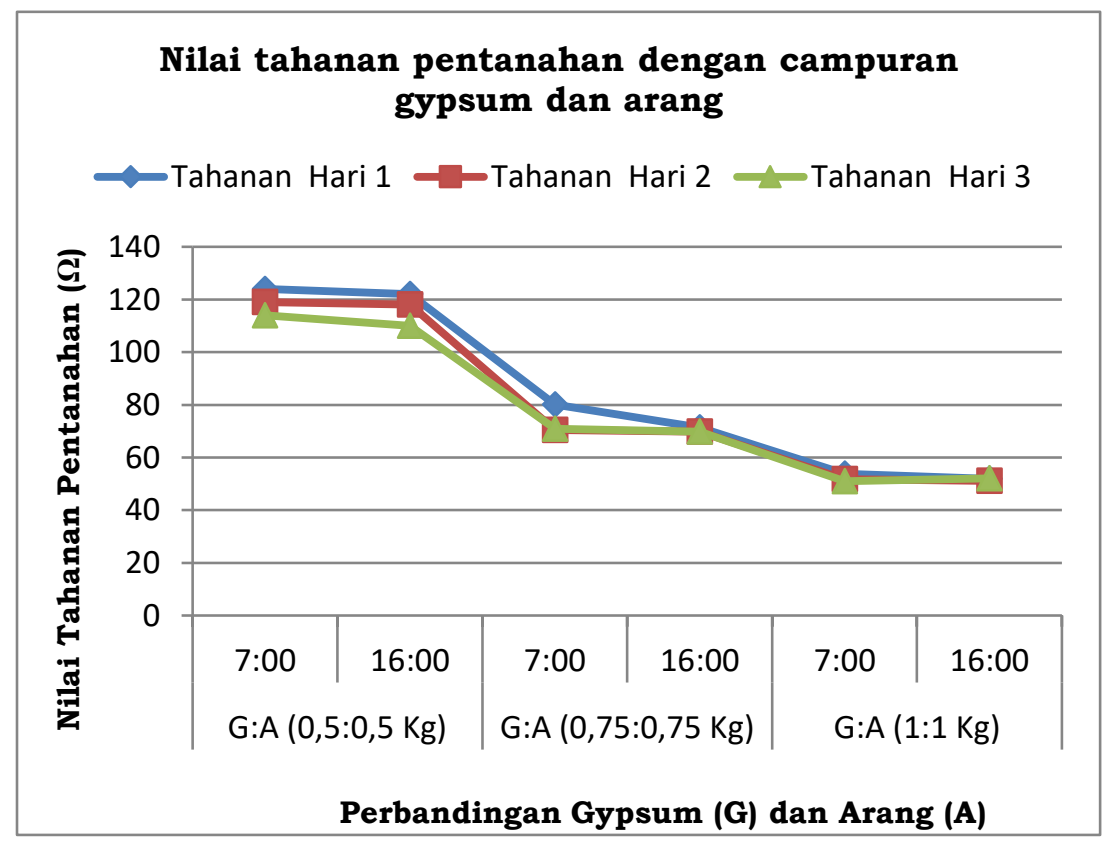

Gambar 9 Grafik hasil pengukuran tahanan pentanahan elektrode $16 \mathrm{~mm}$ secara vertikal dengan campuran gypsum dan arang 
Volume 3 Nomor 1, Januari 2021

Tabel 5 Hasil Pengukuran Tahanan Pentanahan Elektrode $16 \mathrm{~mm}$ (horizontal) dengan Campuran Gypsum dan Arang

\begin{tabular}{|c|c|c|c|c|c|c|c|c|}
\hline \multirow{3}{*}{ NO } & \multirow{3}{*}{ Hari } & \multirow{3}{*}{ Jam } & \multicolumn{6}{|c|}{ Tahanan dan kelembaban tanah } \\
\hline & & & \multicolumn{3}{|c|}{$\begin{array}{c}\text { Tahanan elektrode } 16 \mathrm{~mm}(\Omega) \\
\text { (Horizontal) }\end{array}$} & \multicolumn{3}{|c|}{ Kelembaban tanah (\%) } \\
\hline & & & $\begin{array}{l}\mathrm{G}: \mathrm{A} \\
0,5 \mathrm{Kg}\end{array}$ & $\begin{array}{c}\mathrm{G}: \mathrm{A} \\
0,75 \mathrm{Kg}\end{array}$ & $\begin{array}{l}\mathrm{G}: \mathrm{A} \\
1 \mathrm{Kg}\end{array}$ & $\begin{array}{l}\mathrm{G}: \mathrm{A} \\
0,5 \mathrm{Kg}\end{array}$ & $\begin{array}{c}\mathrm{G}: \mathrm{A} 0,75 \\
\mathrm{Kg}\end{array}$ & $\begin{array}{l}\mathrm{G}: \mathrm{A} \\
1 \mathrm{Kg}\end{array}$ \\
\hline \multirow[t]{2}{*}{1} & \multirow[t]{2}{*}{1} & 07.00 & $121 \Omega$ & $63,7 \Omega$ & $47,5 \Omega$ & $8 \%$ & $9 \%$ & $8 \%$ \\
\hline & & 16.00 & $119 \Omega$ & $63,3 \Omega$ & $46,3 \Omega$ & $7 \%$ & $8 \%$ & $8 \%$ \\
\hline \multirow[t]{2}{*}{2} & \multirow[t]{2}{*}{2} & 07.00 & $98 \Omega$ & $63,6 \Omega$ & $46,5 \Omega$ & $8 \%$ & $7 \%$ & $8 \%$ \\
\hline & & 16.00 & $103 \Omega$ & $63,7 \Omega$ & $46,5 \Omega$ & $6 \%$ & $7 \%$ & $7 \%$ \\
\hline \multirow[t]{2}{*}{3} & \multirow[t]{2}{*}{3} & 07.00 & $91 \Omega$ & $63,3 \Omega$ & $45 \Omega$ & $8 \%$ & $8 \%$ & $8 \%$ \\
\hline & & 16.00 & $91 \Omega$ & $63,7 \Omega$ & $46 \Omega$ & $7 \%$ & $7 \%$ & $6 \%$ \\
\hline \multicolumn{3}{|c|}{ Rata-rata } & $103,83 \Omega$ & $63,55 \Omega$ & $46,3 \Omega$ & $7,3 \%$ & $7,7 \%$ & $7,5 \%$ \\
\hline
\end{tabular}

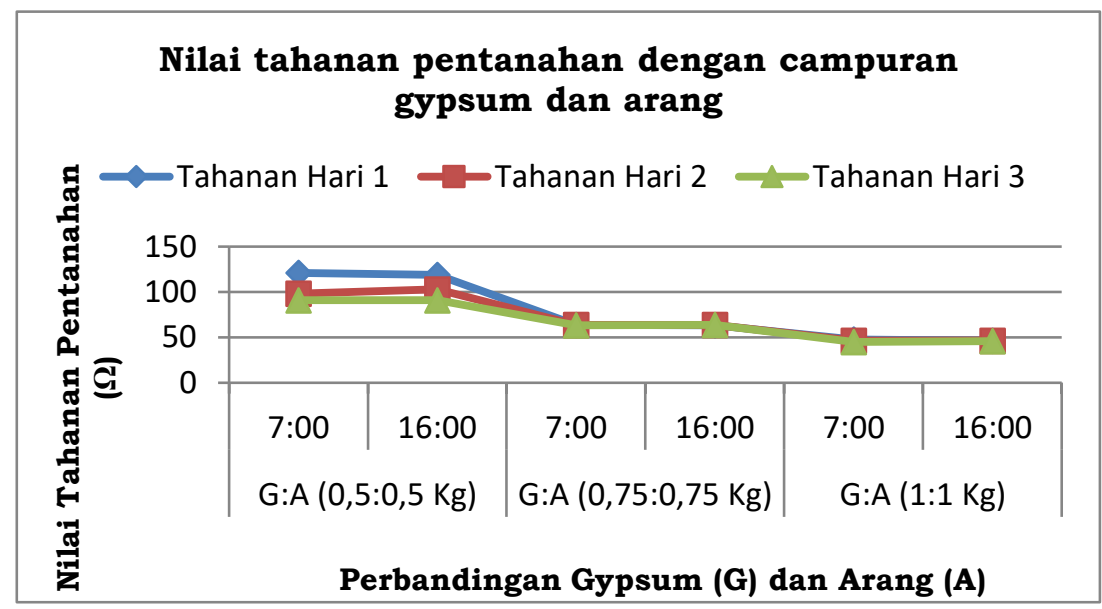

Gambar 10 Grafik hasil pengukuran tahanan pentanahan elektrode $16 \mathrm{~mm}$ secara horizontal dengan campuran gypsum dan arang

C. Pembahasan

Data yang diperoleh dari pengukuran langsung dilapangan didapatkan hasil perbandingan sebagai berikut.

1. Perbandingan Perubahan Konfigurasi Elektrode $12 \mathrm{~mm}$ dan Elektrode $16 \mathrm{~mm}$ Sebelum Ditambahkan Campuran Gypsum dan Arang.

Dari hasil pengukuran menggunakan elektrode $12 \mathrm{~mm}$ dan elektrode $16 \mathrm{~mm}$ seperti yang terlihat pada Tabel 1 dan 2, dapat dilakukan perbandingan guna untuk mengetahui diantara kedua metode tersebut yang manakah yang menghasilkan nilai tahanan pentanahan yang kecil. Gambar 11 menunjukkan grafik perbandingan nilai rata-rata tahanan pentanahan antara perubahan konfigurasi elektrode $12 \mathrm{~mm}$ dengan perubahan konfigurasi elektrode $16 \mathrm{~mm}$ sebelum ditambahkan campuran gypsum dan arang. 
Volume 3 Nomor 1, Januari 2021

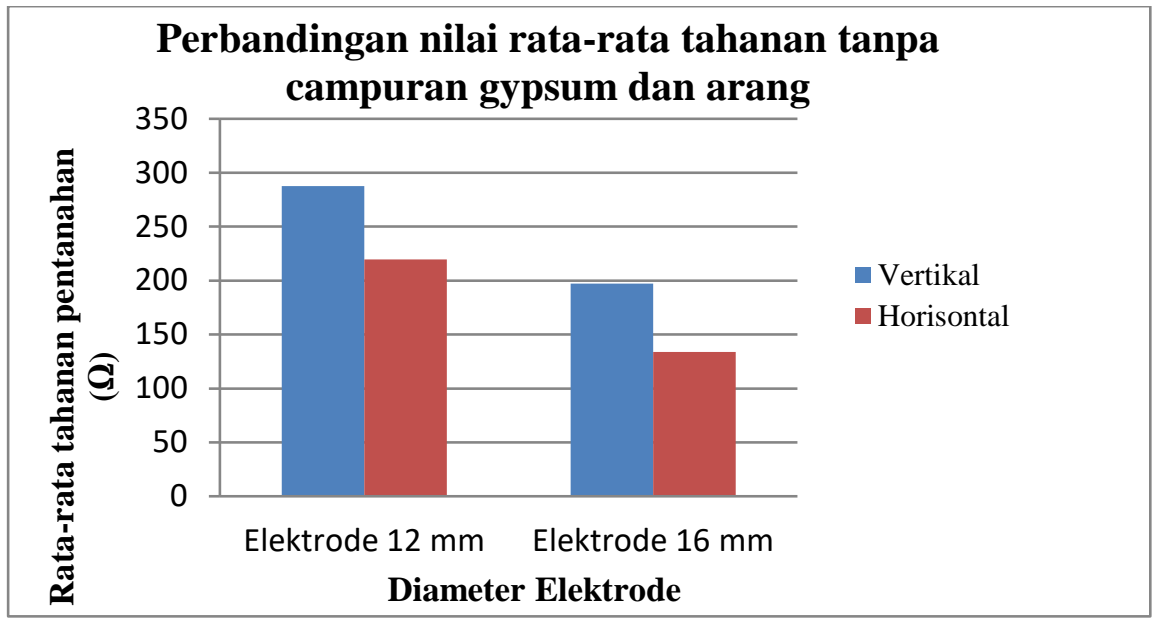

Gambar 11 Grafik perbandingan nilai rata-rata tahanan pentanahan tanpa campuran gypsum dan arang

2. Perbandingan perubahan konfigurasi elektrode $12 \mathrm{~mm}$ dan elektrode $16 \mathrm{~mm}$ setelah ditambahkan campuran gypsum dan arang

Setelah didapatkan data hasil pengukuran elektrode $12 \mathrm{~mm}$ dan elektrode $16 \mathrm{~mm}$ seperti yang terlihat pada Tabel 3-6, maka dapat dilakukan perbandingan. Gambar 12 menunjukkan grafik perbandingan nilai rata-rata tahanan pentanahan antara perubahan konfigurasi elektrode $12 \mathrm{~mm}$ dengan perubahan konfigurasi elektrode $16 \mathrm{~mm}$ setelah ditambahkan campuran gypsum dan arang.

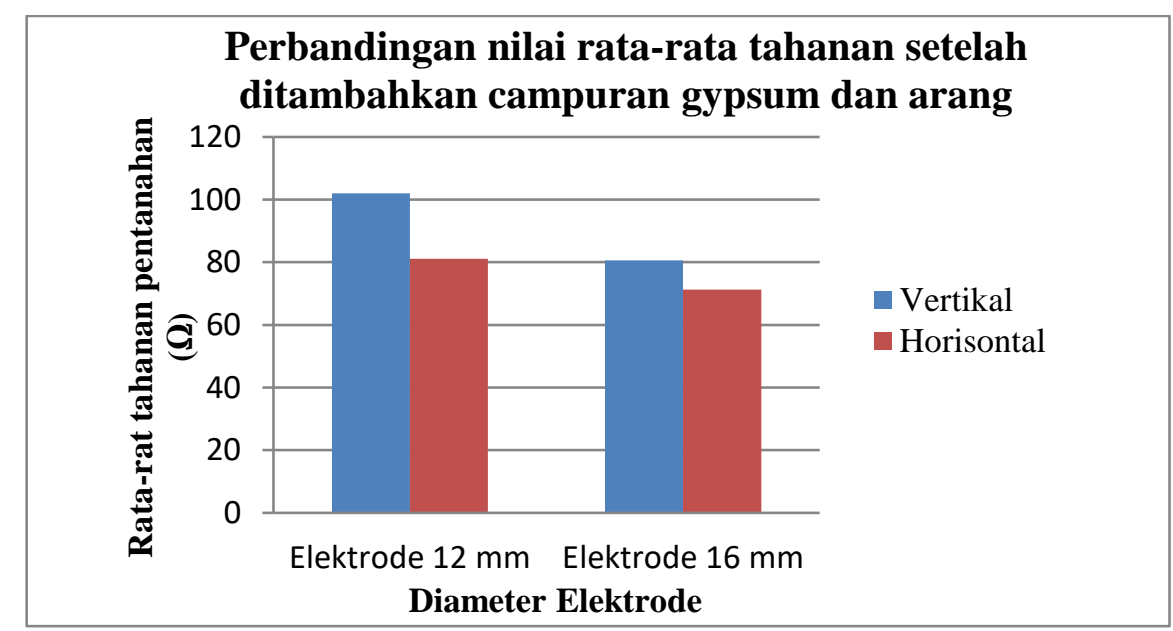

Gambar 12 Grafik perbandingan nilai rata-rata tahanan setelah ditambahkan campuran gypsum \& arang 
3. Perbandingan perubahan konfigurasi elektrode $12 \mathrm{~mm}$ dan elektrode $16 \mathrm{~mm}$ sebelum dan sesudah ditambahkan campuran gypsum dan arang

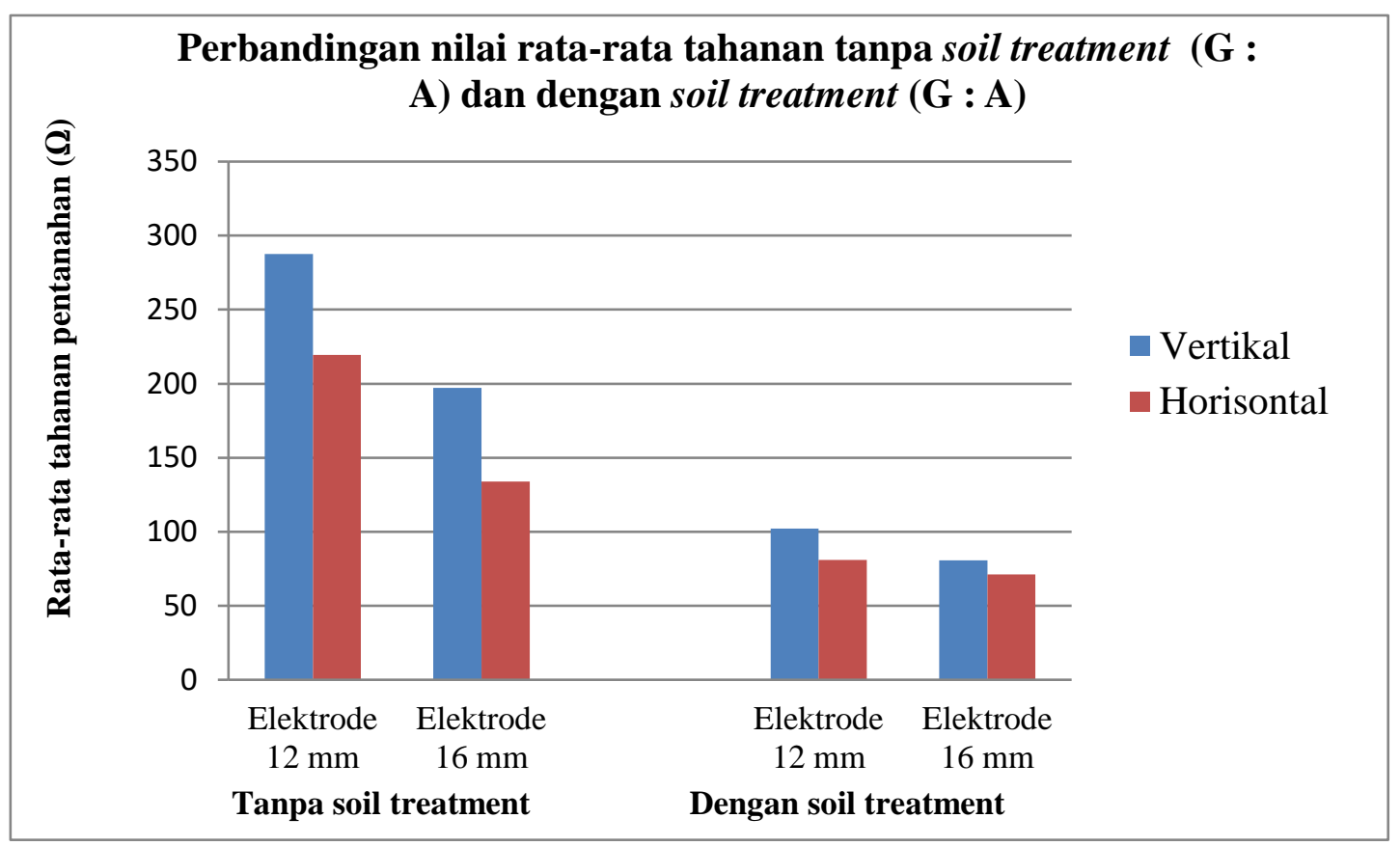

Gambar 13 Grafik perbandingan nilai rata-rata tahanan tanpa soil treatment $(\mathrm{G}: \mathrm{A})$ dan dengan soil treatment $(\mathrm{G}: \mathrm{A})$

Nilai tahanan pentanahan terendah dari setiap pengukuran didapat dari diameter elektrode 16 $\mathrm{mm}$ yang ditanam secara horizontal, dengan penambahan campuran gypsum dan arang pada perbandingan G : A $1 \mathrm{~kg}$ di pengukuran hari ke tiga pukul 07:00 WIB yaitu sebesar $45 \Omega$. Penurunan nilai tahanan ini disebabkan beberapa faktor yaitu semakin besar diameter elektrode yang digunakan maka nilai tahanan akan semakin kecil, dikarenakan dengan luas penampang elektrode yang lebih besar maka arus gangguan dapat tersalurkan dan menyebar dengan cepat didalam tanah. Penambahan campuran gypsum dan arang (soil treatment) dapat menurunkan tahanan pentanahan karena yang sifatnya absorb akan menyerap air tanah dan menjadikan area disekitar elektrode yang tertanam secara horizontal tersebut mendapat kelembaban yang sama sehingga nilai tahanan akan semakin kecil. Ada beberapa faktor yang mempengaruhi tahanan jenis tanah antara lain garam tanah, temperatur tanah, kelembaban dan jenis tanah (Hutahuruk, 1991). Pada saat pagi hari tanah akan menjadi lembab disebabkan oleh embun, dibandingkan pada saat sore hari tanah akan kehilangan kelembabannya terutama pada permukaan dikarenakan adanya panas sinar matahari, dan juga pada saat pengukuran pagi itu sebelumnya telah terjadi hujan dan tanah menjadi sangat lembab (basah) ditambah campran gypsum dan arang yang bersifat absorb (menyerap air tanah) sehingga dapat menurunkan nilai tahanan yang sangat signifikan.

\section{Kesimpulan}

Berdasarkan hasil pengukuran dan analisis data dapat didsimpulkan bahawa:

1. Mengkonfigurasikan penanaman elektrode batang vertikal ke horizontal dengan tambahan campuran gypsum dan arang dapat menurunkan nilai tahanan pentanahan. Pengaruhnya dapat dilihat dari hasil pengukuran langsung secara langsung dilapangan, untuk diameter elektrode $12 \mathrm{~mm}$ baik penanaman 
secara vertikal maupun horizontal semakin besar perbandingan campuran gypsum dan arang yang digunakan dan semakin lama penanamannya akan mempengaruhi penurunan nilai tahanan. Dari hasil pengukuran tersebut, dengan merubah konfigurasi penanaman elektrode batang dapat menurunkan nilai tahanan pentanahan sebesar 20\%. Sedangkan untuk elektrode diameter $16 \mathrm{~mm}$ sama halnya dengan elektrode $12 \mathrm{~mm}$, namun dengan merubah diameter elektrode menjadi lebih besar maka nilai tahanan pentanahan akan semakin turun, hal ini sesuai dengan nilai tahanan yang didapatkan dari pengukuran yang dilakukan secara langsung dilapangan. Dan merubah konfigurasi penanamannya dari vertikal ke horizontal dapat menurunkan nilai tahanan yaitu sebesar $13 \%$.

2. Luas penampang atau diameter elektrode dapat mempengaruhi nilai tahanan pentanahan. Dengan tambahan campuran gypsum dan arang yang berfariasi dan mengubah diameter elektrode batang tunggal $12 \mathrm{~mm}$ menjadi $16 \mathrm{~mm}$ dapat menurunkan nilai tahanan pentanahan sebesar $12 \%$.

\section{Daftar Pustaka}

[1] 80-2000, IEEE Std. (2000). IEEE guide for safety in AC Substation Grounding. IEEE Power Engineering Society.

[2] Abidin, Z., \& Ghufron, A. (2005). Analisa Perbaikan Sistem Pentanahan Instalasi Listrik di Tanah Kapur dan Padas Menggunakan Metode Sigarang (Sistem Grounding Arang dan Garam). Jurnal Teknik Elektro, ISSN 2502-0986, 1-5.

[3] IEEE Std. (2007). IEEE Recommended Practice for Grounding of Industrial and Commercial Power Systems. IEEE Industry Applications Society: Institute of Electrical and Electronics Engineers, Inc.

[4] Muliansyah, D. (2016). Pengaruh suhu dan jenis tanah terhadap nilai tahanan pentanahan di Universitas Bangka Belitung. Kepulauan Bangka Belitung: Universitas Bangka Belitung.

[5] PUIL, 2. (2000). Persyaratan Umum Instalasi Listrik 2000 (PUIL 2000). Jakarta: Yayasan PUIL.

[6] Whitaker. (1952). Safety Aspects of Grounding Portable Equipment. IEEE Journal, 897. 